\title{
Does Shrub Removal Increase Groundwater Recharge in Southwestern Texas Semiarid Rangelands?
}

\author{
Georgianne W. Moore, ${ }^{1}$ David A. Barre, ${ }^{2}$ and M. Keith Owens ${ }^{3}$
}

\author{
Authors are ${ }^{1}$ Assistant Professor, Department of Ecosystem Science and Management, Texas AひM University, College Station, TX 77843, USA; \\ ${ }^{2}$ Research Assistant, Texas AgriLife Extension Center, San Angelo, TX 76901, USA; and ${ }^{3}$ Professor and Department Head, Department of Natural \\ Resource Ecology and Management, Oklahoma State University, Stillwater, OK 74078, USA.
}

\begin{abstract}
Evapotranspiration (ET) is a key component limiting groundwater recharge past the root zone in semiarid regions. Vegetation management may alter groundwater recharge if ET is altered due to changes in vegetation type or cover. This study quantifies changes in groundwater recharge following vegetation cover change from native woodland to pasture in a semiarid region of southwest Texas. The Carrizo-Wilcox aquifer is a valuable groundwater resource in this area, where overuse by dependent farming practices has lowered aquifer levels significantly in the last $85 \mathrm{yr}$. Combining data from short-term $(30 \mathrm{mo})$ monitoring of the changes in soil moisture and long-term (5-30 yr) changes in total soil chloride indicated deep drainage increased slightly where land had been cleared of vegetation. Annual recharge rates below rooting depths (standardized to $155 \mathrm{~cm}$ ) averaged only $0.72 \pm 0.2 \mathrm{~mm} \cdot \mathrm{yr}^{-1}$ (mean $\pm \mathrm{SE}$ ) in areas not cleared of woody vegetation, as estimated by chloride mass balance. Upon clearing, $72 \%$ of the total chloride naturally occurring in the soil profile was flushed away within $30 \mathrm{yr}$, leading to an estimated $2.59 \pm 1.7 \mathrm{~mm} \cdot \mathrm{yr}^{-1}$ additional recharge. Deep soil moisture in recently cleared land increased by up to $17 \%$ during the growing season of wet years (double the average rainfall) but did not increase in dry or normal precipitation years, providing supporting evidence that more water penetrated below the roots under certain environmental conditions. These results demonstrate that brush management can increase recharge by modest, but measurable, amounts depending on site-specific soil characteristics and degree of reduction in vegetation.
\end{abstract}

\section{Resumen}

La evapotranspiración (ET) es un componente clave que limita la recarga de agua subterránea más allá de la zona radicular en regiones semiáridas. El manejo de la vegetación puede alterar la recarga de las aguas subterráneas si se altera la ET por los cambios en la cubierta o el tipo de vegetación. Este estudio midió los cambios de la recarga del agua subterránea después de los cambios en la cubierta de la vegetación de un bosque nativo a un pastizal en una región semiárida del suroeste de Texas. El acuífero de Carrizo-Wilcox es un recurso valioso de las aguas subterráneas en esta zona, donde el uso excesivo debido a las prácticas dependientes de la agricultura ha bajado significativamente los niveles acuíferos en los últimos 85 años. Combinando los datos de seguimiento a corto plazo (30 meses) de los cambios en la humedad del suelo y a largo plazo (5-30 años) en los cambios del total del cloruro de suelo indicaron que el drenaje profundo aumentó ligeramente en áreas donde la vegetación se había aclarado. Las tasas anuales de recarga debajo de la profundidad de la raíz (estandarizado a $155 \mathrm{~cm}$ ) promedió sólo $0.72 \pm 0.2 \mathrm{~mm} \cdot a_{n} \mathrm{no}^{-1}$ en áreas no esclarecidas de vegetación leñosa, estimado por el balance de masa de cloruro. Después del aclareo el $72 \%$ del total del cloruro que ocurre naturalmente en el perfil del suelo fue removido entre 30 años, conduciendo a una estimación de recarga adicional de $2.59 \pm 1.7 \mathrm{~mm} \cdot \mathrm{año}^{-1}$. La humedad del suelo profundo en tierras recientemente aclaradas se incrementó hasta un $17 \%$ durante la estación de crecimiento en años húmedos (doble de la media de la precipitación) pero no aumentó durante años con precipitación normal o años secos, proporcionando pruebas que más agua penetró por debajo de la zona radicular bajo ciertas condiciones ambientales. Estos resultados demuestran que el manejo de arbustivas puede incrementar modestamente la recarga del agua, pero en cantidades medibles, dependiendo de las características especificas del sitio del suelo y el grado de reducción de la vegetación.

Key Words: brush management, Carrizo-Wilcox aquifer, chloride mass balance, deep drainage, natural tracer, soil water balance

\section{INTRODUCTION}

The economic sustainability of many farming regions around the world depends on aquifers. Yet in semiarid areas, aquifers are being depleted alarmingly fast because human use exceeds

Research was funded by the Wintergarden Groundwater Conservation District.

Correspondence: Georgianne W. Moore, Ecosystem Science and Management, 2138 TAMU,

College Station, TX 77843-2138, USA. Email: gwmoore@tamu.edu

Manuscript received 22 March 2011; manuscript accepted 19 August 2011. the recharge. Deep percolation of distributed rainfall contributes positively to groundwater recharge in natural semiarid landscapes at varying rates (Scanlon 1992; Kennettsmith et al. 1994; Scanlon 2000; Scott et al. 2000; Cook and Robinson 2002; Harrington et al. 2002; Petheram et al. 2002; Scanlon et al. 2006), influenced by interactions between climate, soil, and vegetation (Kennettsmith et al. 1994; Harrington et al. 2002; Petheram et al. 2002). Although recharge (Jackson et al. 1996; Scanlon 2000; Scanlon and Cook 2002; Huxman et al. 2004), water balance (Carlson et al. 1990), groundwater 
chemistry, and residence time (Land and Huff 2010) have been well studied in semiarid regions, vegetation factors remain the most dynamic and least understood of the factors affecting recharge.

It is possible for multiyear trends in increased annual precipitation to exceed the water-holding capacity of the soilplant system, leading to deep recharge (Allison et al. 1990; Seyfried et al. 2005). However, recharge below xeric vegetation in upland settings likely occurs in response to conditions that are not met in normal rainfall years (Dong et al. 2003). Episodic recharge events may be possible during unusually wet periods with high antecedent moisture content (Kennettsmith et al. 1994; Petheram et al. 2002; Scanlon et al. 2006). Large precipitation events during the growing season are more likely to promote positive vegetation response, increased aboveground and belowground biomass production, and deeper rooting depths than events during the late fall and winter, when plants are dormant, because xeric, deep-rooted soil-plant systems are highly rain-use efficient (Seyfried et al. 2005). Thus, precipitation is more likely to move to lower depths during plant dormancy than during the peak growing season when there is high evapotranspiration (ET; averages nearly $6 \mathrm{~mm} \cdot \mathrm{d}^{-1}$ during the months of May-August, 2001-2010). ${ }^{1}$

Vegetation management may alter groundwater recharge in semiarid regions if ET is altered, which occurs if changes in vegetation type or cover manipulate available energy or plantavailable water (Moore and Heilman 2011). Tolmie and coworkers (2010) have suggested that a change in land use from native woodland to crop or pasture will lead to more water leaching below the rooting zone and into the groundwater. Even small changes in groundwater percolation due to minor shifts in natural vegetation may have substantial cumulative impacts if the spatial extent of the changes covers a large proportion of the aquifer recharge zone. Furthermore, if management practices maintain vegetation in an altered state for several years to decades, small changes in groundwater percolation may accumulate over time.

Vertical patterns in evaporates, such as chloride, can indicate even small cumulative changes in deep percolation. Chloride mass balance $(\mathrm{CMB})$ is a particularly useful natural tracer technique in semiarid regions where recharge rates are likely below a few millimeters per year (Gee et al. 2005). Others (Scanlon 1991; Phillips 1994; Scanlon 1994; Scanlon 2000; Scanlon et al. 2005) have used the CMB approach to identify maximum extent of wetting fronts and recharge rates in semiarid and arid areas to varying degrees of precision.

This study focused on the Carrizo-Wilcox aquifer, a valuable groundwater resource located in a major agricultural region within a semiarid landscape of southwest Texas. Groundwater levels of the Carrizo-Wilcox aquifer have lowered by about $30 \mathrm{~m}$ in the last $85 \mathrm{yr}$ (Texas Water Development Board). ${ }^{2}$ Our study sites were situated above the Carrizo-Wilcox recharge zone, where the aquifer intersects the land surface and gains most of its water inputs. Stream-channel recharge into the Carrizo-Wilcox aquifer varies widely (ranging between $2.5 \mathrm{~mm} \cdot \mathrm{yr}^{-1}$ and $147 \mathrm{~mm} \cdot \mathrm{yr}^{-1}$, Scanlon et al. 2003).

\footnotetext{
'http:// texaset.tamu.edu

${ }^{2}$ http://www.twdb.state.tx.us
}

Above the Carrizo-Wilcox aquifer, soil chloride flushing was observed within 5-15 yr following brush clearing as a consequence of the change in vegetation type and subsequent shallower root distribution (Moore et al. 2010). We applied the CMB technique to chloride profiles that Moore et al. (2010) previously observed in this study area, and took additional measurements over an extended area in the Carrizo-Wilcox recharge zone and over a longer chronosequence. The aim of this research was to track differences in deep drainage following the clearing of natural shrub vegetation and subsequent regrowth of shrubs over 5-30 yr; we expected to see increases in deep drainage in grass-dominated plots postclearing. We also monitored soil moisture over a 30-m period to determine local soil moisture trends below the maximum root zone during wet and dry periods. We evaluated these trends to determine whether short-term deep drainage pulses occurred in this system, and if so, how often and under what land management they occurred.

\section{METHODS}

\section{Site Description}

This study included the three sites near the city of Cotulla, Texas (lat $28^{\circ} 27^{\prime} 03^{\prime \prime} \mathrm{N}$, long $99^{\circ} 11^{\prime} 02^{\prime \prime} \mathrm{W}$ ), previously reported in Moore et al. (2010; hereafter referred to as the "T" sites), consisting of three treated (cleared) plots and a control (naturally vegetated) plot at each of the three site locations within a 150-ha area. In the cleared plots, shrubs had been cleared by root plow $15 \mathrm{yr}, 5 \mathrm{yr}$, or less than $1 \mathrm{yr}$ prior to our study; the sites had subsequently been allowed to regrow naturally. (Plots cleared less than 1 yr prior to study-referred to as "0-yr" plots-were used only for soil moisture measurements, as detailed below.) Data from nine additional sites within a $50-\mathrm{km}^{2}$ area centered on Carrizo Springs in southwest Texas (lat $28^{\circ} 26^{\prime} 11^{\prime \prime} \mathrm{N}$, long $99^{\circ} 14^{\prime \prime} 12^{\prime \prime} \mathrm{W}$ ) were also collected (hereafter referred to as the "Z" sites; Table 1). Each of the $\mathrm{Z}$ sites consisted of adjacent paired plots within a $50-\mathrm{m}$ distance: one was shrub-dominated rangeland (control), and the other had been cleared of brush 5-30 yr ago by root plow (treatment). Additional follow-up treatments, if any, are indicated in Table 1. Soil chloride responses to brush removal were determined by direct comparison of control and treatment pairs. The $\mathrm{Z}$ sites were distributed over the Carrizo-Wilcox aquifer recharge zone. Two of the $Z$ sites were located in the Wilcox aquifer recharge zone (Sites Z2 and Z9), and seven in the Carrizo aquifer recharge zone (Table 1). Individual landowners provided information about the management history, treatment dates, and the type of treatment utilized to control the brush (Table 1). Long-term weekly precipitation records (1946-2010) were obtained from the weather station at the Cotulla Airport, ${ }^{3}$ centrally located within the study area.

\section{Soils and Vegetation}

The study area's gently undulating landscape is composed primarily of moderately deep to deep sandy and sandy loam soils of moderate to high permeability (Table 1). Soils in the local area surrounding the study sites belong predominantly to

\footnotetext{
${ }^{3}$ http://www.noaa.gov
} 
Table 1. Site descriptions including landscape position, percentage of slope, location in contributing zone (CZ) or recharge zone (RZ), management history (all nearby control sites were native shrubland), soil texture of A and B horizons (sand [s], clay [c], loam [I]), and US Geological Survey soil series.

\begin{tabular}{|c|c|c|c|c|c|}
\hline Site & Landscape position & Aquifer & Management & Field soil texture & Soil series \\
\hline $\mathrm{T} 1$ & $\begin{array}{l}\text { Gently sloping }(<2 \%) \\
\text { low backslope }\end{array}$ & $\mathrm{CZ}$ & $\begin{array}{l}\text { Root-plowed }<1 \mathrm{yr}, 5 \mathrm{yr} \text {, and } 15 \mathrm{yr} \text { ago, } \\
\text { left to regrow, cattle grazing }\end{array}$ & A: scl, B: sc & Webb \\
\hline T2 & $\begin{array}{l}\text { Very slight lower } \\
\text { slope }(<2 \%)\end{array}$ & $\mathrm{CZ}$ & $\begin{array}{l}\text { Root-plowed }<1 \mathrm{yr}, 5 \mathrm{yr} \text {, and } 15 \mathrm{yr} \text { ago, } \\
\text { left to regrow, cattle grazing }\end{array}$ & A: scl, B: sc & Duval \\
\hline T3 & Slight upper slope $(<2 \%)$ & $\mathrm{CZ}$ & $\begin{array}{l}\text { Root-plowed }<1 \mathrm{yr}, 5 \mathrm{yr} \text {, and } 15 \mathrm{yr} \text { ago, } \\
\text { left to regrow, cattle grazing }\end{array}$ & $\begin{array}{l}\text { A: sl, B: scl, 15-yr } \\
\text { and control a } \\
\text { bit sandier }\end{array}$ & Webb and Duva \\
\hline $\mathrm{Z1}$ & $\begin{array}{l}\text { Very slight convex } \\
\text { midslope }(<1 \%)\end{array}$ & Carrizo RZ & $\begin{array}{l}\text { First root-plowed about } 30 \mathrm{yr} \text { ago, } \\
\text { maintained as pasture with fire every } 5 \mathrm{yr}\end{array}$ & A: sl, B: scl & Antosa \\
\hline Z2 & Ridgeline $(<2 \%)$ & Wilcox RZ & $\begin{array}{l}\text { Strip root-plowed } 30 \mathrm{yr} \text { ago, left to } \\
\text { regrow, originally cattle grazing but now } \\
\text { only deer }\end{array}$ & A: scl, B: scl & Webb \\
\hline $\mathrm{Z3}$ & Slight upper slope $(<2 \%)$ & Nueces River, Carrizo RZ & $\begin{array}{l}\text { First root-plowed } 30 \mathrm{yr} \text { ago, plowed every } \\
5 \mathrm{yr} \text { to remove regrowth, cattle grazing }\end{array}$ & A: sl, B: scl & Bobillo \\
\hline Z4 & Slight midslope $(<2 \%)$ & Carrizo RZ & $\begin{array}{l}\text { Root-plowed } 20 \mathrm{yr} \text { ago, maintained as } \\
\text { pasture for the } 20 \mathrm{yr} \text { since, cattle } \\
\text { grazing and feed grown }\end{array}$ & A: sl, B: scl & Bobillo \\
\hline $\mathrm{Z} 5$ & Lower slope (2\%) & Carrizo RZ & $\begin{array}{l}\text { First root-plowed about } 20 \text { yr ago, } \\
\text { maintained as pasture by plowing } \\
\text { every } 5 \text { yr, occasional crop grown, } \\
\text { possible irrigation }\end{array}$ & $\mathrm{A}: \mathrm{scl}, \mathrm{B}: \mathrm{cl}$ & Webb \\
\hline Z6 & Slight upper slope $(<1 \%)$ & Wilcox RZ & $\begin{array}{l}\text { Root-plowed about } 20 \mathrm{yr} \text { ago, left to regrow, } \\
\text { cattle grazing }\end{array}$ & $\mathrm{A}$ : Is or $\mathrm{sl}, \mathrm{B}$ : $\mathrm{sl}$ & Antosa \\
\hline $\mathrm{Z7}$ & Convex upper slope $(<1 \%)$ & Carrizo RZ & $\begin{array}{l}\text { First root-plowed about } 30 \mathrm{yr} \text { ago, maintained } \\
\text { as pasture by plowing and fire every } \\
5 \mathrm{yr} \text { or as needed }\end{array}$ & $\mathrm{A}: \mathrm{sl}, \mathrm{B}: \mathrm{scl}$ & Bobillo \\
\hline Z8 & Relatively flat & Carrizo RZ & $\begin{array}{l}\text { First root-plowed about } 30 \mathrm{yr} \text { ago, } \\
\text { maintained every } 5 \mathrm{yr} \text { with } \\
\text { plowing, cattle grazing }\end{array}$ & A: scl, B: sc & Webb \\
\hline $\mathrm{Z9}$ & $\begin{array}{l}\text { Very slight lower } \\
\text { slope }(<1 \%)\end{array}$ & Carrizo RZ & $\begin{array}{l}\text { Root-plowed about } 30 \text { yr ago, left to } \\
\text { regrow, cattle grazing }\end{array}$ & $\mathrm{A}:$ Is or $\mathrm{sl}, \mathrm{B}: \mathrm{sl}$ & Antosa \\
\hline
\end{tabular}

the Antosa (Arenic Paleustalfs) and Bobillo (Grossarenic Paleustalfs) series with minor groups in the Duval (Aridic Haplustalfs) and Webb (Aridic Paleustalfs) series. Control plots were native, undisturbed stands of rangeland brush dominated by mature honey mesquite (Prosopis glandulosa Torr.). The prevailing brush-clearing method was to root-plow vegetation using a horizontal blade that cuts the roots $30 \mathrm{~cm}$ below ground level. Such root plowing usually results in bare ground. Typically, grasses quickly reestablish within the first year following brush removal, whereas woody plants do not reach original densities until at least $15 \mathrm{yr}$ later (Moore et al. 2010).

\section{Soil Samples}

Over a period of $3 \mathrm{mo}$, from July 2007 to September 2007, two soil cores were collected from each Z plot, except for Z9, from which only one soil core was collected. Collection methods were the same as those used to collect soil cores from the T plots, which were sampled in 2006 as detailed by Moore et al. (2010). Briefly, the distance between the two cores within each plot was approximately $2 \mathrm{~m}$. A Giddings soil auger was used to excavate $50-\mathrm{mm}$ diameter cores from depths of up to $2.7 \mathrm{~m}$. The exact depth of each soil core was limited by the machinery's physical dimensions and power, and depended highly on the depth to rock or any other impenetrable layer encountered, such as gravel or highly compacted silt. Soil cores were divided into $10-\mathrm{cm}$ depth increments that were sampled according to anticipated chloride variability at $0-10 \mathrm{~cm}, 10-20 \mathrm{~cm}$, every $20 \mathrm{~cm}$ to $180 \mathrm{~cm}$, and every $30 \mathrm{~cm}$ to the bottom of the core. The number of samples per core ranged from 9 to 18 , depending on the total depth of the core. If possible, the bottom 10-cm increment was sampled even if it fell outside the sampling protocol depths.

Soil profile samples were used to characterize a variety of soil descriptive parameters, including volumetric water content, bulk density, gravel fraction, $\mathrm{pH}$, electrical conductivity, and chloride concentration. Aqueous extracts were taken from the soil samples at each sampling depth. The New Mexico Bureau of Geology and Mineral Resources analyzed the water extract for chloride using ion chromatography. Dilutions done in the lab to produce the water extracts for chloride were calculated back to undiluted concentrations and then further converted to pore-water chloride concentrations using gravimetric water content at the time of sampling. 


\section{Soil Moisture}

Over $30 \mathrm{mo}$, we investigated daily, weekly, and monthly changes in volumetric water content at the $\mathrm{T}$ sites. Soil moisture samples were concentrated at the $\mathrm{T}$ sites because of the costs of the equipment and installation, and the accessibility of the sites. The $\mathrm{Z}$ sites were not available for the repeated visits necessary for collecting these data. Two different techniques were used: one instrument recorded volumetric water content continuously (Ech2o, Decagon Devices, Inc., Pullman, WA), whereas another monitored volumetric water content periodically throughout the year (Diviner 2000, Sentek Sensor Technologies, Australia). To capture immediate effects of plowing, soil moisture was monitored in 0 -yr plots, those that had been rootplowed less than a year before. These plots were not suitable for chloride sampling because insufficient time had elapsed for chloride leaching. The Ech2o probes located at site T1 and T2 in 0 -yr, 5-yr, 15-yr, and control plots were buried within a single excavated pit on the undisturbed exposed soil face at 20$\mathrm{cm}, 40-\mathrm{cm}, 70-\mathrm{cm}$, and $200-\mathrm{cm}$ depths. Continuous data were recorded at 30-min intervals. Sixty-four polyvinyl chloride access tubes for the Diviner 2000 probe were distributed throughout sites T1, T2, and T3 in 0-yr, 5-yr, 15-yr, and control plots, with each plot having five access tubes. Soil moisture was recorded in $10-\mathrm{cm}$ increments, from $10 \mathrm{~cm}$ to $160 \mathrm{~cm}$, on the following dates: 25 May and 7 July 2005, 2 May and 12 July 2006, and 12 April and 9 July 2007, at T1, $\mathrm{T} 2$, and $\mathrm{T} 3$, respectively. These periods encompass times of high plant growth and high ET. To estimate potential deep recharge, we used only the $200-\mathrm{cm}$ depth of the Ech2o probes and the average soil moisture between $120 \mathrm{~cm}$ and $160 \mathrm{~cm}$ in depth for the Diviner probes. Average soil moisture $(\theta)$ was computed for each profile at these depths and expressed as the difference in deep soil moisture between the two dates each

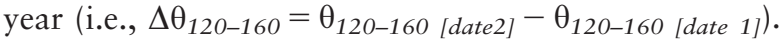

\section{Chloride Deposition}

Chloride deposition records were obtained for a 23-yr period (1984-2006) from the National Atmospheric Deposition Program, ${ }^{4}$ and were collated to provide average chloride depositions for the two closest known observation points to the study area: Beeville, approximately $130 \mathrm{~km}$ east, and Sonora, approximately $260 \mathrm{~km}$ northwest. A linear distanceweighted interpolation of monthly chloride deposition values was made from those values obtained for each of the two observation stations. The interpolated rate of monthly chloride wet and dry deposition for the $\mathrm{T}$ sites (Cotulla) was $0.59 \mathrm{mg} \cdot \mathrm{L}^{-1} \cdot \mathrm{yr}^{-1}$. For simplicity, all sites were assigned the same chloride deposition rate, given that exact deposition rates in situ were not measured and that all sites were within $50 \mathrm{~km}^{2}$. Accurate recharge estimates depend on quality atmospheric chloride input data. We assumed that dry and wet deposition from the atmosphere was the only source of chloride input to subsurface layers, because the only other potential sources are marine deposits, applied fertilizer, or irrigation water.

${ }^{4}$ http://nadp.sws.uiuc.edu

\section{Chloride Mass Balance}

$\mathrm{CMB}$ can be expressed as

$$
P C_{P}=D_{D} C_{S},
$$

where $P$ is the precipitation $\left(\mathrm{mm} \cdot \mathrm{yr}^{-1}\right), C_{P}$ is the chloride concentration by atmospheric deposition $\left(\mathrm{mg} \cdot \mathrm{L}^{-1}\right), D_{D}$ is the rate of deep drainage $\left(\mathrm{mm} \cdot \mathrm{yr}^{-1}\right)$, and $C_{S}$ is the chloride concentration $\left(\mathrm{mg} \cdot \mathrm{L}^{-1}\right)$ in the soil pore water at a depth of interest-see Scanlon et al. (2009) for detailed methodology. Precipitation was recorded at T1 and T2 using tipping bucket rain gauges and a CR10X datalogger (Campbell Scientific, Logan, UT); any gaps in the record were filled using data from nearby weather stations (NOAA 2002) at the airports of either Cotulla (for $\mathrm{T}$ sites) or Carrizo Springs ( $\mathrm{Z}$ sites). Rearranging Equation 1 to solve for $D_{D}$ gives

$$
D_{D}=P C_{P} / C_{S} .
$$

As detailed above, $P$ was measured, $C_{P}$ was fixed at $0.59 \mathrm{mg} \cdot \mathrm{L}^{-1} \cdot \mathrm{yr}^{-1}$, and $C_{S}$ was calculated from soil sample measurements. We calculated $D_{D}$ (Equation 2) below two target depths as follows. A conservative approach used $C_{S}$ measured at the bottom-most depth common to plots within each site, but this approach complicates comparisons between sites differing in sampling depth. Standardization was necessary to enable direct comparisons between paired plots. To standardize across profiles, recharge estimates were also calculated using $C_{S}$ measured at $155 \mathrm{~cm}$ in all profiles. Fifty percent of the root biomass was above $25 \mathrm{~cm}$ and $95 \%$ was above $150 \mathrm{~cm}$ at the T sites (Moore et al. 2010). Only two of the profiles on one control plot had $95 \%$ of the root biomass contained in a greater depth $(175 \mathrm{~cm})$. We subtracted $D_{D}$ estimates in control plots from their associated, paired treatment-plot estimates to estimate the additional yearly recharge for the time since vegetation had been cleared. So, for example, the additional yearly recharge $\left(\Delta D_{D}\right)$ at site T1 in the 5 -yr plot would be calculated for both the bottom-most depth and to the standard depth of $155 \mathrm{~cm}$ as follows:

$$
\Delta D_{D[\mathrm{~T} 1,5 \text {-yr }]}=D_{D[\mathrm{~T} 1,5-\mathrm{yr}]}-D_{D[\mathrm{~T} 1, \mathrm{control}]} .
$$

\section{Statistical Analysis}

Analysis of variance (ANOVA; SPSS Inc.) allowed testing for differences in average and maximum soil bulk density between treatments that may have altered soil hydraulic conductance. Likewise, we used ANOVA to examine treatment effects on three chloride variables: maximum (or "peak") chloride concentration expressed per unit soil mass $\left([\mathrm{Cl}]_{\max }\right)$, depth-topeak concentration $\left(d_{\mathrm{Cl}}\right)$, and total chloride accumulated in the profile $\left(\Sigma_{\mathrm{Cl}}\right)$. As noted above, we did not sample or analyze chloride in 0 -yr plots established strictly for soil moisture monitoring. This procedure was repeated for both the standard depth of $155 \mathrm{~cm}$ and the bottom-most depth common to each site pair. ANOVA followed by multiple comparisons using Fisher's Protected LSD test was also used to compare soil moisture changes between plots within three consecutive years, from April to July, resulting from root plowing at the T sites. We 


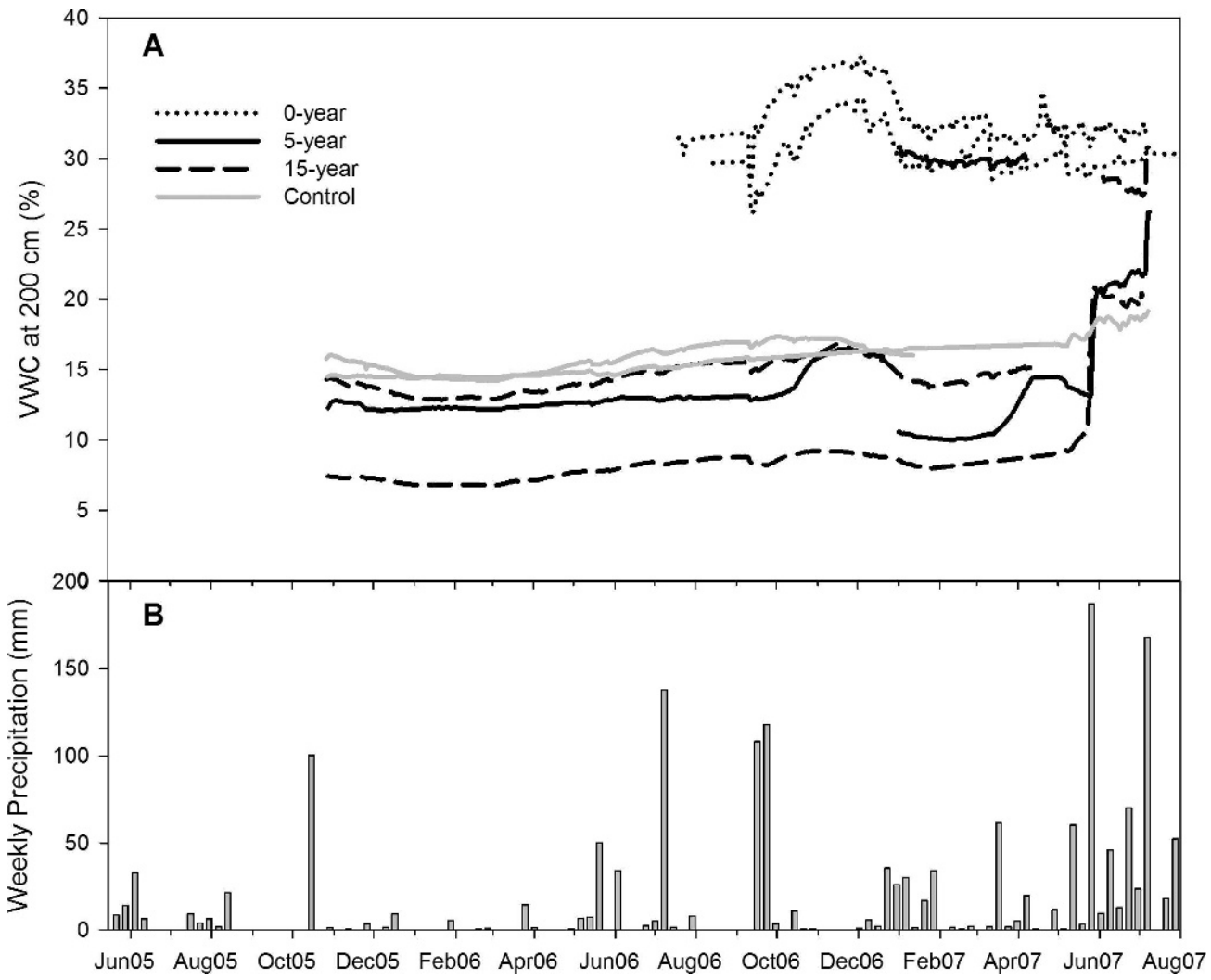

Figure 1. A, Sites T1 and T2: continuous volumetric water content (VWC, \%) at $200 \mathrm{~cm}$ depth for control (solid gray), 15-yr (dashed), 5-yr (solid black) and 0-yr (dotted) plots between October 2005 and July 2007. Continuous data were not available for 0-yr plots until July 2006. B, Weekly precipitation totals.

used Studentized paired $t$ tests to compare $D_{D}$ between cleared (treated) and uncleared (control) plots at a given location.

\section{RESULTS}

\section{Annual Variation in Deep Drainage}

Over the past $30 \mathrm{yr}$, mean annual rainfall was $604 \mathrm{~mm}$ and $526 \mathrm{~mm}$ at the $\mathrm{T}$ and $\mathrm{Z}$ sites, respectively. During the 3-yr study, we experienced a dry year, a normal year, and a wet year (Fig. 1). We focused on the months of May, June, and July, which averaged $248 \mathrm{~mm}$ from 1946-2010. The year 2005 was dry during that period, with only $97 \mathrm{~mm}$ of precipitation. The period from May through July of 2006 was normal, with $241 \mathrm{~mm}$ of precipitation. May through July 2007, however, was considerably wetter, having nearly twice the normal precipitation, $480 \mathrm{~mm}$.

Trends in continuous volumetric water content deep in the profiles $(200 \mathrm{~cm})$ indicate consistently wet conditions $(>25 \%)$ from July 2006 on (when data were available) in the 0 -yr plots at T1 and T2 and the 5-yr plot at T1 (Fig. 1). By contrast, conditions were consistently dry and stable $(<20 \%)$ in all other plots throughout the first $2 \mathrm{yr}$ of the study. For much of the time, there was no evidence of water movement deep in the profile. Then in late May 2007, following a large rain event (weekly total was $187 \mathrm{~mm}$ ), we observed rapid increases in soil moisture at

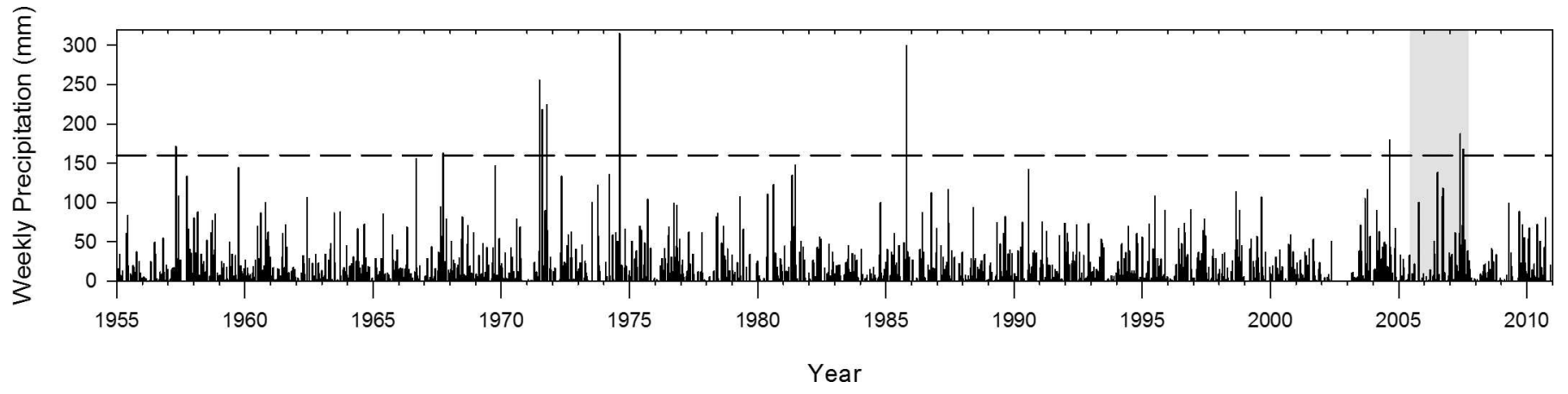

Figure 2. Weekly total precipitation (mm) at the Cotulla Airport from 1946 to 2010. Line at $160 \mathrm{~mm}$ indicates probable threshold for deep drainage events based on soil moisture observations. 


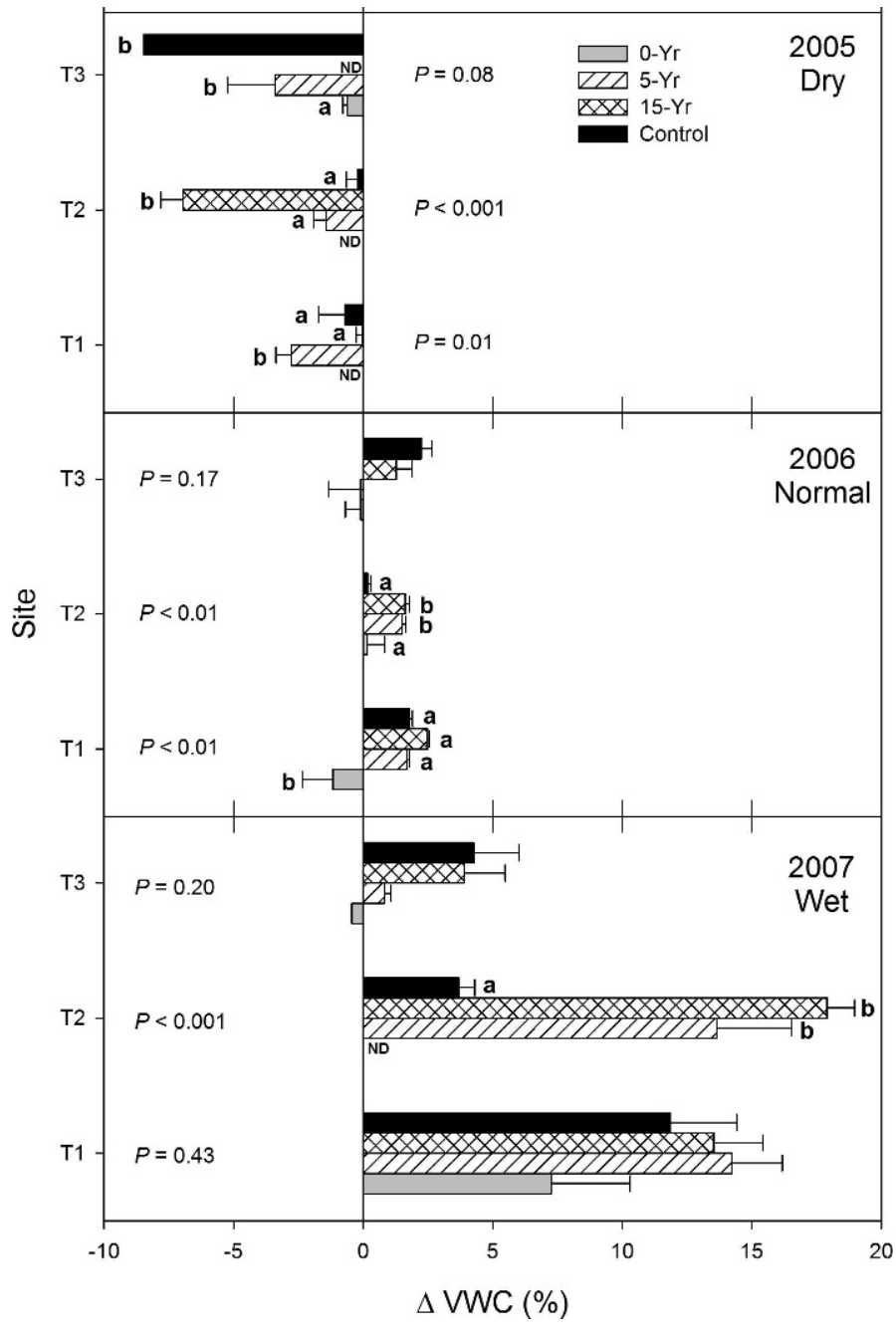

Figure 3. Change in average soil volumetric water content ( $\triangle \mathrm{VWC}, \%)$, for the depths 120-160 cm, between root-plow treatments at each T site for 2005 (days 145-188), 2006 (days 122-193), and 2007 (days 122193). ND indicates plots without data for these dates.

$200 \mathrm{~cm}$ in the 5 -yr and 15 -yr plots to levels above $20 \%$, which is the approximate level of saturation in these soils (Dunne and Leopold 1978). This was the only deep drainage event observed in the 3-yr study. The long-term record indicates weekly totals exceeded $160 \mathrm{~mm}$ only 10 times since 1947: April 1957, September 1967, June 1971, August 1971, October 1971, August 1974, October 1985, August 2004, May 2007, and July 2007 (Fig. 2). The presumed threshold amount of $160 \mathrm{~mm}$ was chosen conservatively because we observed 1 wk in July 2006 and $2 \mathrm{wk}$ in September 2006 with high rainfall (yet less than $160 \mathrm{~mm}$ ) that did not cause rapid rises in deep drainage.

Data from the Diviner instrument also indicated that high rainfall during May, June, and July of 2007 led to as much as $17 \%$ increases in deep soil moisture at $120-160 \mathrm{~cm}$, and those increases were more pronounced in root-plowed plots at T2 (Fig. 3, $P<0.001$ ). By contrast, T1 and T3 saw similar increases in deep soil moisture among all plots, regardless of whether and when they were root-plowed $(P>0.20)$. In the dry rainfall year of 2005, however, volumetric water content decreased by $0-8 \%$ for deep soil layers between May and July
2005, despite almost $50 \mathrm{~mm}$ of rain during May (Fig. 3). In this dry period, deep soil moisture declined the most in the control plot at T3, by $8 \%$ (note there was only one functioning soil moisture access tube at this site). Declines in control plots at sites T1 and T2 were similar to those observed for 15-yr and 5 -yr plots, respectively, but more pronounced declines were observed in the 5-yr plot at site T1 $(P=0.01)$ and the 15 -yr plot at site T2 $(P<0.001)$. The same period in 2006 had normal rainfall amounts, during which volumetric water content at depth increased slightly, by about $2 \%$ in the $15-\mathrm{yr}, 5-\mathrm{yr}$, and control plots at two of the three sites (Fig. 3). At T2, 5-yr and 15 -yr treated plots showed more response $(P<0.01)$ in 2006 than control plots. At T1, control, 5-yr, and 15-yr plots showed the same modest increases in 2006 while modest declines were observed the 0 -yr plot $(P<0.01)$, possibly because the 0 -yr plot was wet to begin with.

\section{Long-Term Deep Drainage Following Brush Clearing}

We found no difference in soil bulk density between the treated and untreated paired plots that could confound the observed changes in deep drainage in the years following root plowing $(P>0.05$, $t$-test comparison of bulk density in plowed and control T sites at $20-\mathrm{cm}$ depth). Chloride mass concentrations with depth for each profile are shown in Figure 4 for all $\mathrm{Z}$ sites (refer to Moore et al. 2010 for T site data). Patterns were similar between replicate samples taken at the same location. Middle depths had more chloride and greater peak chloride concentrations among untreated (control) plots compared with the cleared plots (Fig. 4). Indeed, cleared plots had only $28 \%$ of the total chloride stored in the soil profiles down to $155 \mathrm{~cm}$ $\left(\Sigma_{\mathrm{Cl}}\right.$ reduced from $1336 \pm 489 \mathrm{~kg} \cdot \mathrm{ha}^{-1}$ to $379 \pm 109 \mathrm{~kg} \cdot \mathrm{ha}^{-1}$; $P<0.05)$. This result closely matched observed differences at the $\mathrm{T}$ sites, where cleared plots after $5 \mathrm{yr}$ had $27 \%$ of the total chloride down to $205 \mathrm{~cm}$ (Moore et al. 2010). Within 15-30 yr at the $\mathrm{Z}$ sites, $[\mathrm{Cl}]_{\max }$ was reduced by about $66 \%$ or $268 \pm 97 \mathrm{~kg} \cdot \mathrm{ha}^{-1}(P<0.05)$. Furthermore, the depth to maximum chloride concentrations flushed about $24 \mathrm{~cm}$ lower in that time (from $146 \pm 20 \mathrm{~cm}$ down to $170 \pm 20 \mathrm{~cm}$ ). These $\mathrm{Z}$-site results were more modest than those found at the $\mathrm{T}$ sites, where depth to maximum chloride concentration had increased nearly a meter in the 5-yr plots (Moore et al. 2010).

We found deep drainage occurring at almost every location, even at untreated plots (Fig. 5), but the amounts were small and highly variable. Over all 15 site pairs, $D_{D}$ below the standard depth of $155 \mathrm{~cm}$ more than quadrupled in the years following treatment compared to the untreated plots (from $0.72 \pm$ $0.2 \mathrm{~mm} \cdot \mathrm{yr}^{-1}$ to $\left.3.30 \pm 1.6 \mathrm{~mm} \cdot \mathrm{yr}^{-1} ; P<0.05\right)$. The same trend continued to the bottom of each core although this more conservative calculation lowered $D_{D}$ estimates to $1.60 \pm$ $0.5 \mathrm{~mm} \cdot \mathrm{yr}^{-1}$ in treatment plots and $0.58 \pm 0.2 \mathrm{~mm} \cdot \mathrm{yr}^{-1}$ in control plots $(P<0.05)$. Thirteen of 15 pairs exhibited increased yearly recharge in cleared areas over adjacent unmanaged areas, derived from both the standardized (Fig. 6) and conservative calculations. Only at site Z3 did $D_{D}$ apparently decrease in the years after clearing, by $1.44 \mathrm{~mm} \cdot \mathrm{yr}^{-1}$ at $155 \mathrm{~cm}$ deep, but this deficit became a surplus of $3.3 \mathrm{~mm} \cdot \mathrm{yr}^{-1}$ at a depth of $265 \mathrm{~cm}$. Over the years following treatment, root plowing increased $D_{D}$ by $2.59 \pm 1.7 \mathrm{~mm} \cdot \mathrm{yr}^{-1}$ to $155-\mathrm{cm}$ depths and by $1.01 \pm$ $0.5 \mathrm{~mm} \cdot \mathrm{yr}^{-1}$ measured to the bottom of each core. 


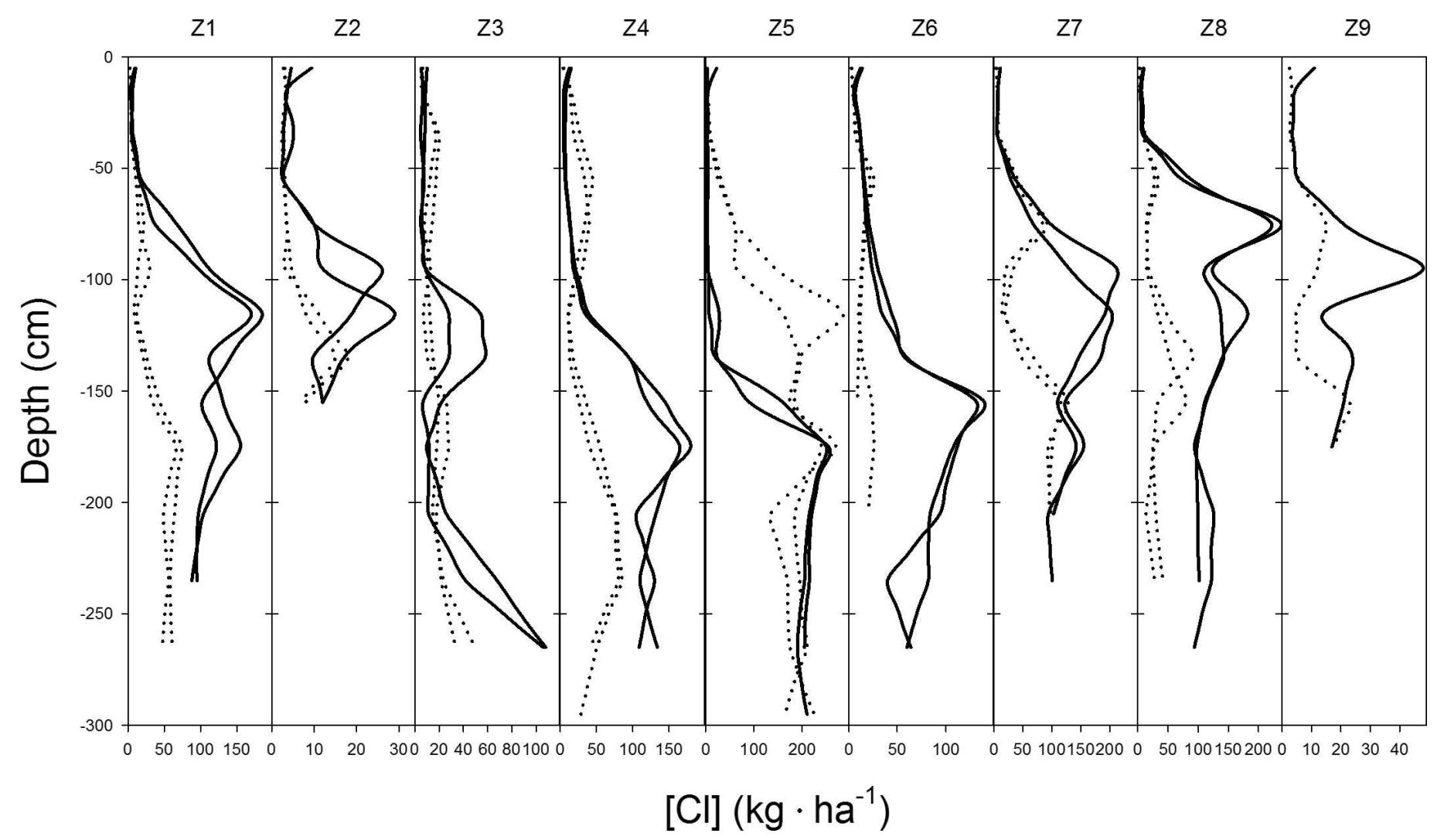

Figure 4. Chloride concentration with depth for each of the nine Carrizo (Z) sites. Solid lines indicate control (naturally vegetated) plots; dotted lines, treatment (cleared) plots. Chloride concentrations with depth at the three T sites are reported by Moore et al. (2010).

\section{DISCUSSION}

Short-term soil moisture trends and long-term soil chloride distributions observed on rangelands in different stages of regrowth clearly indicated that brush clearing facilitated small increases in deep drainage below the root zone. Hypothetically, this water has the potential to recharge the Carrizo-Wilcox aquifer. However, such small incremental pulses of deep drainage are unlikely to produce measurable benefits for two reasons. First, there will be a long time lag between deep drainage and aquifer recharge because the aquifer is $91 \mathrm{~m}$ below the surface. It is unknown how long it would take for minor pulses to percolate that distance because the permeability changes with the geology (Dunne and Leopold 1978). Second, the long-term rate of aquifer drawdown from overuse is $35 \mathrm{~cm}$ per year, which clearly exceeds the amount of recharge, even if large areas were root-plowed. The net result, thus, is not sustainable.

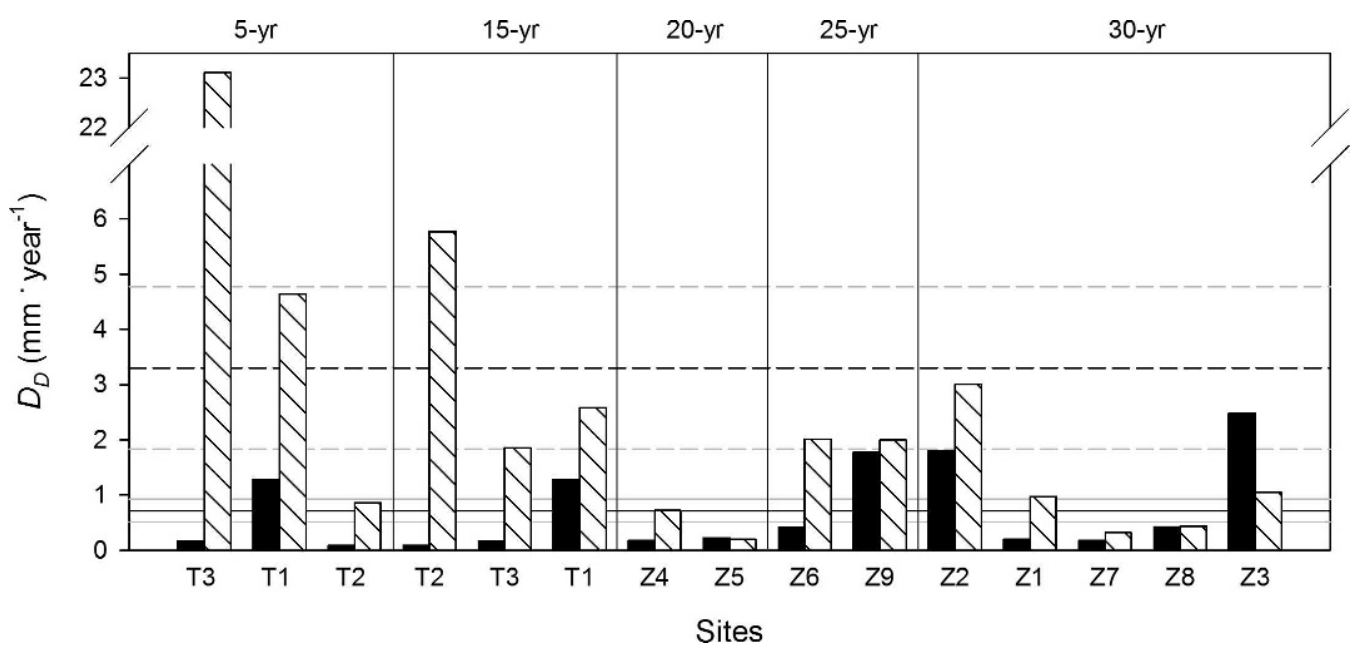

Figure 5. Yearly recharge estimates, $D_{D}$, for all Cotulla $(\mathrm{T})$ and Carrizo $(Z)$ sites below $155 \mathrm{~cm}$ (standardized). Untreated control (black bars) is paired with an adjacent brush-clearing treatment (striped bars) at each site. Lines indicated overall means (black) and standard errors (gray) for control (solid line) and treatment (dashed line). 


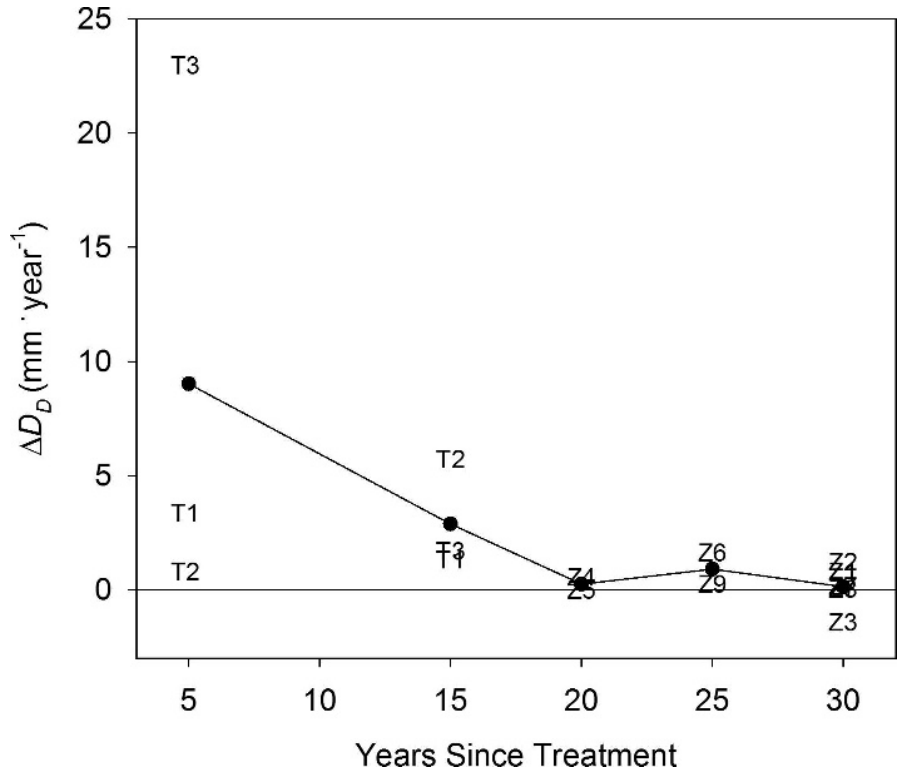

Figure 6. Amount of additional recharge due to brush-clearing treatments $\left(\Delta D_{D}\right)$ for all Cotulla $(\mathrm{T})$ and Carrizo $(Z)$ sites below $155 \mathrm{~cm}$ (standardized) in relation to years since treatment. Thirteen of 15 sites had positive $\Delta D_{D}$, indicating additional deep drainage following treatment. Yearly averages (line-dots) indicate the temporal trend.

In this region, it takes a very rare event, on the order of once every $7 \mathrm{yr}$, to send a pulse of water far down into the profile. We observed a dynamic increase in deep soil moisture during a year with above-normal rainfall, but not during moderate or dry rainfall years, which led us to conclude that recharge events occur only under unusually wet conditions. Only 10 times over the past $64 \mathrm{yr}$ had weekly total precipitation exceeded $160 \mathrm{~mm}$, a probable threshold for deep drainage to occur. A $179-\mathrm{mm}$ event in August 2004 might have been the only significant deep drainage event to have altered soil chloride concentrations deep in the profile of our paired plots treated less than $15 \mathrm{yr}$ prior to this study. Before that, there were no probable recharge events for many years back to the 300-mm event in October 1985, which likewise might have greatly influenced chloride differences observed in $\mathrm{Z}$ plots plowed at least $22 \mathrm{yr}$ ago.

Wetting fronts from typical rain events probably do not extend past the root zone. Soils at the bottom of the root zone remained dry (below the estimated saturated water content of $20 \%$ ) during below-normal rainfall years (such as 2005), with no potential for deep drainage. The same is likely true of normal rainfall years because we observed only $0-2 \%$ increases in volumetric water content during 2006. Clearly, dry or normal conditions may persist in semiarid regions for many years without producing any recharge, regardless of land use.

When the soil is finally wet enough, perhaps because of repeated events close in time, a single large rain event such as observed in summer 2007 may produce a greater recharge pulse on cleared land. We did not detect a pulse of recharge in dry soils below uncleared rangelands, only deep within soils below vegetation that was treated $5 \mathrm{yr}$ and $15 \mathrm{yr}$ previously (Fig. 1). Most compelling, soils below recently treated sites without shrubs apparently stayed wet continuously (refer to 0 -yr plots shown in Fig. 1). Such patterns may be the result of varying ET among sites. Our results are consistent with growing evidence that between-year variability in soil moisture storage depends on soil and vegetation characteristics (Allison et al. 1990; Huxman et al. 2004; Seyfried et al. 2005).

It is critical to point out that soil moisture increased during a wet growing season despite high potential ET rates averaging $6 \mathrm{~mm} \cdot \mathrm{d}^{-1}$ compared with $2 \mathrm{~mm} \cdot \mathrm{d}^{-1}$ or less in the winter months. ${ }^{5}$ This is vital evidence that differences in vegetation can impact antecedent moisture and subsequent pulses of water deep in the profile even during the growing season. Since the 1940s, most events have occurred in the growing season or early fall in association with tropical storms. Deep drainage events are even more likely when potential ET is lower and vegetation is senescing or dormant. Following significant rainfall in late September and early October 2006, we observed slow and modest increases in deep soil moisture over the course of several months in the winter of 2006 (Fig. 1). For unknown reasons, increases were most pronounced in $0-\mathrm{yr}$ and 5 -yr plots and hardly detectable in the control plots. Because most vegetation was dormant in the winter, these dynamics might have been driven by slow downward diffusion of vapor. Moisture contents declined to background levels again in the early spring.

Native vegetation in this region roots primarily above $155 \mathrm{~cm}$, so any water that moves past this depth may potentially recharge the aquifer. No roots were found below $155 \mathrm{~cm}$ in 11 out of 18 cores at the T sites (Moore et al. 2010), similar to predicted root depths in Schenk and Jackson (2002) for this biome. In some cases, however, further root uptake may occur below $155 \mathrm{~cm}$, given that $D_{D}$ estimates declined by an average of $20 \%$ between $155 \mathrm{~cm}$ and the bottom of each profile. Certainly mesquite roots reach to these depths (Heitschmidt et al. 1988) but the majority of absorbing roots tend toward the upper layers of the soil (Schenk 2008). Weltz and Blackburn (1995) used a soil depth of $200 \mathrm{~cm}$ to determine deep drainage in a vegetation type similar to that in this study.

Vegetation cover can impact recharge, but so can soil properties such as bulk density and preferential flow pathways (Hendrickx and Yao 1996), which are at least as important as vegetation cover (Wilcox et al. 2008). Evidently, spatial variation in soil properties necessitates a high sampling density, which we were unable to achieve in both time and space simultaneously. The most likely explanation for inconsistencies among plots with the same treatment is minor differences in soils, despite finding no measurable differences in bulk density at the surface. For the same reason, short-term soil moisture response to the summer 2007 event did not match up exactly with long-term $D_{D}$ estimates in the same plot measured in cores less than $5 \mathrm{~m}$ away. Inconsistencies between short-term and long-term estimates might also be related to uncertainties inherent to the CMB method (Scanlon 2000). It is important to note that atmospheric deposition of chloride is a continual process, as a part of rainfall or through the dry deposition of dust. Each time rainfall occurs, the chloride infiltrates the soil with the precipitation and continues to depth until the pore water transporting it either evaporates or is taken up by roots near the surface. During wet periods there is potential for a portion of this upper-profile chloride to leach downwards at rates dependent on soil hydraulic properties.

\footnotetext{
${ }^{5}$ http://texaset.tamu.edu
} 
We found evidence that soil chloride was flushed deeper into the profile by wetting fronts. Total soil chloride was halved in the $5 \mathrm{yr}$ following treatment; $15-30 \mathrm{yr}$ after brush clearing, about two-thirds of the original chloride was flushed below the root zone. This finding for a semiarid region contrasts with studies in arid environments largely devoid of flushing events. For example, Scanlon (1991) suggests that the pattern of chloride concentrations with depth in arid regions indicates a long history of chloride buildup.

Our estimates of recharge of $<1 \mathrm{~mm} \cdot \mathrm{yr}^{-1}$ on unmanaged rangelands and $4 \mathrm{~mm} \cdot \mathrm{yr}^{-1}$ on areas that had been root-plowed are similar to those reported by Carlson et al. (1990), who suggest that $0.5-1.4 \%$ of annual precipitation drained below $300 \mathrm{~cm}$ in a north Texas rangeland cleared of brush. Their lysimeter data showed this increase in deep drainage in plots mechanically cleared of mesquite compared to vegetated plots. The soils studied, however, had higher silt and clay content, and were not mechanically disturbed; these characteristics could have impeded water percolation. We observed the greatest contrast between paired plots at site T3, where the deep drainage rate in plots treated only $5 \mathrm{yr}$ before was $23 \mathrm{~mm} \cdot \mathrm{yr}^{-1}$. Water percolation at this site was facilitated by low bulk density, lower than at any other site, especially in the treated area.

Declining trends in the deep drainage rates indicate that brush clearing may not have long-lasting benefits to recharge. The chronosequence of $0 \mathrm{yr}, 5 \mathrm{yr}$, and $15 \mathrm{yr}$ since clearing replicated at the three $\mathrm{T}$ sites provided some indication of the timing of recharge in response to vegetation change. Recharge was dramatically greater within the initial $5 \mathrm{yr}$ after clearing, but this effect diminished by $15 \mathrm{yr}$ as shrub vegetation reestablished from $<1 \%$, to $3 \%$ after $5 \mathrm{yr}$, and $27 \%$ after $15 \mathrm{yr}$, compared with $66 \%$ shrub cover in control plots (Moore et al. 2010). This is not surprising as other studies have reported increased ET by herbaceous (Dugas et al. 1998) or woody plants not killed by the treatment (Moore and Owens 2006). An alternative explanation might be that there were not sizable precipitation pulses in the first $10 \mathrm{yr}$ after the 15 -yr plots were plowed, and instead, chloride built up during this time. However, very small increases in the deep drainage rate were still apparent after $30 \mathrm{yr}$ at four out of five sites in this study. Another way to detect that changes have occurred postclearing is to look for secondary bulges in chloride, which occur as newly accumulated chloride in surface layers. Secondary bulges were evident in several $\mathrm{Z}$ treatment plots (refer to Z5 and Z7 in Fig. 4).

\section{MANAGEMENT IMPLICATIONS}

Results provide valuable scientific input for land managers seeking effective strategies to manage semiarid rangelands over deep aquifers. We present evidence that brush management in semiarid rangelands can increase recharge past the majority of the root zone by modest, but measurable, amounts depending on site-specific soil characteristics and degree of reduction in vegetation. We found a small amount of recharge was occurring even on unmanaged rangelands, albeit less than $1 \mathrm{~mm} \cdot \mathrm{yr}^{-1}$, and predict that land cleared of brush will yield approximately $4 \mathrm{~mm} \cdot \mathrm{yr}^{-1}$ more recharge on average. Root plowing on well-drained sites has the greatest potential to increase recharge; the maximum recharge observed was $23 \mathrm{~mm} \cdot \mathrm{yr}^{-1}$. Nonetheless, this modest amount of potential recharge cannot offset the current rate of aquifer drawdown; thus, root plowing on upland sites in this region is not a sustainable means of increasing water supply. This work contributes novel evidence to the ongoing debate about whether brush control can increase water supplies and can inform policy decisions related to brush management in this region, such as been done in other regions of Texas (Texas Brush Control Program 1985).

\section{ACKNOWLEDGMENTS}

Research was conducted on the Northcut Ranch. We also wish to thank Bobby Ayela, Ed Walker, Rose Cooper, Tim Rogers, Michele Redmond, and Ileana Buican for their assistance.

\section{LITERATURE CITED}

Allison, G. B., P. G. Cook, S. R. Barnett, G. R. Walker, I. D. Jolly, and M. W. Hughes. 1990. Land clearance and river salinization in the western Murray Basin, Australia. Journal of Hydrology 119:1-20.

Carlson, D. H., T. L. Thurow, R. W. Knight, and R. K. Heitschmidt. 1990. Effect of honey mesquite on the water-balance of Texas rolling plains rangeland. Journal of Range Management 43:491-496.

Cook, P. G., And N. I. RoBinson. 2002. Estimating groundwater recharge in fractured rock from environmental H-3 and $\mathrm{Cl}-36$, Clare Valley, South Australia. Water Resources Research 38:1136-1149.

Dong, W. Q., Z. B. Yu, AND D. Weber. 2003. Simulations on soil water variation in arid regions. Journal of Hydrology 275:162-181.

Dugas, W. A., R. A. Hicks, And P. Wright. 1998. Effect of removal of Juniperus ashei on evapotranspiration and runoff in the Seco Creek watershed. Water Resources Research 34:1499-1506.

Dunne, T., AND L. B. Leopold. 1978. Water in environmental planning. New York, NY, USA: W. H. Freeman and Co. 818 p.

Gee, G. W., Z. F. Zhang, S. W. Tyler, W. H. Albright, and M. J. Singleton. 2005. Chloride mass balance: cautions in predicting increased recharge rates. Vadose Zone Journal 4:72-78.

Harrington, G. A., P. G. Cook, and A. L. Herczeg. 2002. Spatial and temporal variability of ground water recharge in central Australia: a tracer approach. Ground Water 40:518-527.

Heitschmidt, R. K., R. J. Ansley, S. L. Dowhower, P. W. Jacoby, and D. L. Price. 1988. Some observations from the excavation of honey mesquite root systems. Journal of Range Management 41:227-231.

HendRICKX, J. M. H., AND T. YAO. 1996. Prediction of wetting front stability in dry field soils using soil and precipitation data. Geoderma 70:265-280.

Huxman, T. E., K. A. Snyder, D. Tissue, A. J. Leffler, K. Ogle, W. T. Pockman, D. R. Sandquist, D. L. Potts, and S. Schwinning. 2004. Precipitation pulses and carbon fluxes in semiarid and arid ecosystems. Oecologia 141:254-268.

Jackson, R. B., J. Canadell, J. R. Ehleringer, H. A. Mooney, 0. E. Sala, and E. D. Schulze. 1996. A global analysis of root distributions for terrestrial biomes. Oecologia 108:389-411.

KennetTSmith, A., P. G. Cook, AND G. R. WALKeR. 1994. Factors affecting groundwater recharge following clearing in the south western Murray Basin. Journal of Hydrology 154:85-105.

Land, L., AND G. F. Huff. 2010. Multi-tracer investigation of groundwater residence time in a karstic aquifer. Roswell, New Mexico, USA: Bitter Lakes National Wildlife Refuge. Hydrogeology Journal 18:455-472.

Moore, G. W., D. A. Barre, and M. K. Owens. 2010. Changes in soil chloride following shrub removal and subsequent regrowth. Geoderma 158:148-155. 
Moore, G. W., and J. L. Heilman. 2011. Ecohydrology bearings-invited commentary: proposed principles governing how vegetation changes affect transpiration. Ecohydrology 4:351-358.

Moore, G. W., AND M. K. OWENs. 2006. Removing adult overstory trees stimulates growth and transpiration of conspecific juvenile trees. Rangeland Ecology \& Management 59:416-421.

[NOAA] National Oceanic and Atmospheric Administration. 2002. Climatography of the United States no. 81. Monthly station normals of temperature, precipitation, heat and cooling degree days 1971-2000. National Oceanic and Atmospheric Administration. Available at: http://www.ncdc.noaa.gov.

Petheram, C., G. Walker, R. Grayson, T. Thierfelder, and L. Zhang. 2002. Towards a framework for predicting impacts of land-use on recharge: 1. A review of recharge studies in Australia. Australian Journal of Soil Research 40:397-417.

Phillips, F. M. 1994. Environmental tracers for water-movement in desert soils of the American Southwest. Soil Science Society of America Journal 58:15-24.

Scanlon, B. R. 1991. Evaluation of moisture flux from chloride data in desert soils. Journal of Hydrology 128:137-156.

Scanlon, B. R. 1992. Moisture and Solute flux along preferred pathways characterized by fissured sediments in desert soils. Journal of Contaminant Hydrology 10: 19-46.

Scanlon, B. R. 1994. Water and heat fluxes in desert soils. 1. Field studies. Water Resources Research 30:709-719.

Scanlon, B. R. 2000. Uncertainties in estimating water fluxes and residence times using environmental tracers in an arid unsaturated zone. Water Resources Research 36:395-409.

Scanlon, B. R., And P. G. Cook. 2002. Theme issue on groundwater rechargepreface. Hydrogeology Journal 10:3-4.

Scanlon, B. R., A. R. Dutton, and M. Sophocleous. 2002. Groundwater recharge in Texas. Austin, TX, USA: The University of Texas at Austin, Bureau of Economic Geology, Texas Water Development Board. 62 p.
Scanlon, B. R., K. E. Keese, A. L. Flint, L. E. Flint, C. B. Gaye, W. M. Edmunds, and I. Simmers. 2006. Global synthesis of groundwater recharge in semiarid and arid regions. Hydrological Processes 20:3335-3370.

Scanlon, B. R., R. C. Reedy, D. A. Stonestrom, D. E. Prudic, and K. F. Dennehy. 2005. Impact of land use and land cover change on groundwater recharge and quality in the southwestern US. Global Change Biology 11:1577-1593.

Scanlon, B. R., D. A. Stonestrom, R. C. Reedy, F. W. Leaney, J. Gates, and R. G. Cresswell. 2009. Inventories and mobilization of unsaturated zone sulfate, fluoride, and chloride related to land use change in semiarid regions, southwestern United States and Australia. Water Resources Research 45:W00A18.

SCHENK, H. J. 2008. The shallowest possible water extraction profile: a null model for global root distributions. Vadose Zone Journal 7:1119-1124.

Schenk, H. J., And R. B. Jackson. 2002. The global biogeography of roots. Ecological Monographs 72:311-328.

Scott, R. L., W. J. Shuttleworth, T. O. Keefer, and A. W. Warrick. 2000. Modeling multiyear observations of soil moisture recharge in the semiarid American Southwest. Water Resources Research 36:2233-2247.

Seyfried, M. S., S. Schwinning, M. A. Walvoord, W. T. Pockman, B. D. Newman, R. B. Jackson, and E. M. Phillips. 2005. Ecohydrological control of deep drainage in arid and semiarid regions. Ecology 86:277-287.

SPSS. 2005. SPSS guide to data analysis, release 14.0. Old Tappan, NJ, USA: SPSS. $652 \mathrm{p}$.

Texas Brush Control Program. 1985. Texas Senate Bill 1083. Acts of the 69th Legislature. Title 7, Chapter 203.

Tolmie, P. E., D. M. Silburn, and A. J. W. Biggs. 2011. Deep drainage and soil salt loads in the Queensland Murray-Darling Basin using soil chloride: comparison of land uses. Soil Research 49:408-423.

Weltz, M. A., and W. H. BlackBurn. 1995. Water-budget for South Texas rangelands. Journal of Range Management 48:45-52.

Wilcox, B. P., P. I. Taucer, C. L. Munster, M. K. Owens, B. P. Mohanty, J. R. Sorenson, and R. BAZAN. 2008. Subsurface stormflow is important in semiarid karst shrublands. Geophysical Research Letters 35:L10403. doi:10.1029/2008GL033696 